\title{
In vitro evaluation of bio-control agents and fungicides against Ganoderma lucidum causing basal stem rot of arecanut
}

\author{
RANJANA CHAKRABARTY*and T.C. SARMA \\ Regional Agricultural Research Station, Assam Agricultural University, Shillongani, Nagaon 782002 , Assam, India \\ Department of Botany, Gauhati University, Guwahati 781014, Assam, India
}

Received: 4 July 2017/ Accepted: 14 August 2017/ Published online: 31 August 2017

(C) Indian Phytopathological Society 2017

\begin{abstract}
Basal stem rot or Ganoderma wilt caused by Ganoderma lucidum (Curtis Ex.Fr.) Karst is one of the major constraints in arecanut cultivation in Assam, India. Pure culture of Ganoderma was isolated from fruiting bodies of diseased arecanut palms. Twenty-two Trichoderma spp. and twelve Pseudomonas fluorescens isolates were prepared from rhizosphere of healthy arecanut palms from different locations. The study was carried out during 2012-13 and 2013-14. Dual culture study revealed that among the Trichoderma spp., $T$. viride Tv-16 isolate, produced maximum reduction in radial growth of $G$. lucidum (88.56\%) followed by Ta-7 and Ta-10 with 88.26 and 84.07 per cent inhibition over control after 144 hrs of incubation respectively. Among the twelve isolates of $P$. fluorescens, Pf6 was most effective, followed by Pf10 with 77.55 and 77.33 per cent inhibition over control, respectively. Seven fungicides were assayed for their efficacy against the test pathogen at 0.1 , 0.2 and 0.3 per cent concentration. Among the systemic fungicides, hexaconazole 5EC and tridemorph $80 \mathrm{EC}$ completely inhibited the growth of G. lucidum at all the concentrations. Among the contact fungicides, mancozeb $75 \%$ WP $(86.11 \%$ inhibition over control) gave maximum control against the pathogen. Compatibility study of fungicides with $T$. viride Tv-16 revealed that the systemic fungicides, carbendazim $50 \%$ WP, hexaconazole $5 \% E C$ and tridemorph $80 \% E C$ were highly sensitive to $T$. viride with 100 per cent inhibition at all the tested concentration. Non-systemic fungicide mancozeb $75 \%$ WP was found to be compatible, whereas copper oxychloride $50 \%$ WP and captan $50 \%$ WP showed low to moderate degree of compatibility with $T$. viride Tv16.
\end{abstract}

Keywords: Arecanut, basal stem rot, fungicides, Pseudomonas fluorescens, Trichoderma spp.

Basal stem rot or Ganoderma wilt caused by Ganoderma lucidum (Curtis Ex. Fr.) Karst is the most dreaded disease of arecanut in Assam since it causes damage to the product as well as the crop. Butler (1909) reported the disease on cash crops such as coconut, betelnut and other plantation crops like Casuarina, Acacia, Dalbergia sisso and Toona ciliate in the North Eastern States of India. It is a cosmopolitan fungus and causes white rot of woody plants by decomposing lignin, cellulose and polysaccharides. The disease has not only affected the productivity but also wiped out arecanut plantations in certain localities. The disease is severe in neglected, ill drained and over-crowded orchards. Disease incidence was reported as high as 77 per cent in Goalpara district of Assam. Although control measures using fungicides are reported to be effective, it becomes very difficult for large scale application. Moreover, with the increased awareness on toxic hazards of chemicals to crops, consumers and the environment, exploration of some innovative techniques for the management of the disease has become imperative. Biological control holds promise as a strategy for disease management and it is environment friendly too. Antagonistic fungi especially

${ }^{*}$ Corresponding author: ranjana_74@yahoo.co.in
Trichoderma species and bacteria Bacillus subtilis and fluorescent Pseudomonads have been widely used against a number of phytopathogens. Currently studies pertaining to the use of bio-control agents in management of diseases are highly emphasized (Leelavathi et al., 2014). Bhaskaran et al. (1988) studied the antagonistic potentiality of $T$. harzianum and $T$. hamatum against $G$. Iucidum and found that application of neem cake encouraged the saprophytic soil microflora especially Trichoderma spp. in coconut basins and was effective in the control of the disease. In addition, the compatibility of fungicides has been considered to be the most important criterion with regards to integrated disease management (IDM). The compatibility of fungicides with bio-control agents is desirable with a view to reduce their cost of application. A number of fungicides had been tested for their compatibility with most commonly used fungal antagonists, Trichoderma spp., many of which have been reported to be compatible with T. harzianum (Sharma et al., 2001).

Considering the economic loss of the crop, the present study was undertaken to elucidate the efficacy of bio-control agents and fungicides and their compatibility under in vitro condition with an objective of developing an IDM strategy. 


\section{MATERIALS AND METHOD}

\section{Isolation of the test fungus}

A total of thirty samples were collected (sporophores, bark and roots) during survey from different districts of Assam. The samples were collected in fresh polythene bags and brought in to the laboratory for isolation. The diseased samples were cut into small convenient pieces, sterilized in $0.1 \% \mathrm{HgCl}_{2}$ for one minute, then washed thrice in sterile distilled water and plated on Ganoderma selective media. Pure culture was transferred into slants and maintained on Potato Dextrose Agar media for further study.

\section{Isolation and in vitro efficacy study of biocontrol agents}

The isolation of the bio-control agents was done from the rhizosphere of healthy arecanut palms from different districts of Assam using serial dilution plate technique. Bio-control agents, Trichoderma spp. and P. fluorescens were isolated on Trichoderma selective media (Elad and Chet, 1983) and on King's B media, respectively. Trichoderma spp. and $P$. fluorescens were tested against G. Iucidum on PDA media by using dual culture technique (Dhingra and Sinclair, 1985). Twenty $\mathrm{ml}$ of sterilized and cooled PDA was poured into sterile petridishes and allowed to solidify. In case of Trichoderma spp., mycelial discs of test fungus were inoculated at one end of petriplates and antagonistic fungus was placed opposite to it on the other end. In case of evaluation of $P$. fluorescens, the bacterium was streaked at both ends of petriplates and mycelial disc of the fungus was placed at the centre. A petriplate was inoculated only with $G$. lucidum that served as control. Each experiment was replicated three times and incubated at $28 \pm 2^{\circ} \mathrm{C}$ and radial growth of the pathogen was recorded in both treated and control plates. The per cent inhibition over control was calculated.

The values obtained in different categories were transformed, wherever necessary and subjected to statistical analysis for comparison.

\section{In vitro efficacy study of fungicides}

Seven fungicides (four systemic and three non-systemic) were assayed for their efficacy against the test pathogen at $0.1,0.2$ and $0.3 \%$ concentration by using poisoned food technique. The required quantities of fungicides were thoroughly mixed in the medium before pouring into petridishes so as to get the desired concentration of active ingredient of each fungicide separately. Twenty $\mathrm{ml}$ of fungicide amended medium was poured in each of $90 \mathrm{~mm}$ sterilized petridishes and allowed to solidify. The plates were inoculated centrally with $7 \mathrm{~mm}$ disc of six days old culture of $G$. lucidum. The control without fungicides was maintained. The experiment was conducted in completely randomized design (CRD) with three replications. Petriplates were incubated at $28 \pm 2{ }^{\circ} \mathrm{C}$. The radial growth was measured up to six days and per cent inhibition of growth over control was calculated.
In vitro compatibility study of fungicides with biocontrol agent

In vitro study was undertaken to determine the compatibility of both systemic and non-systemic fungicides with a bio-control agent (Trichoderma virideTv16, a fungal antagonist) to determine the suitability of these fungicides in IDM system following poisoned food technique. The PDA medium amended with a series of concentrations $(0.1,0.2$ and $0.3 \%)$ of test fungicides in petriplates with replicated treatments were inoculated at their centers with $7 \mathrm{~mm}$ diameter mycelial discs of freshly growing cultures of $T$. viride taken from the periphery of culture plate. The inoculated plates were incubated at $28 \pm 2^{\circ} \mathrm{C}$. Observations were recorded on the radial growth after $144 \mathrm{hrs}$ of incubation. Control was maintained with PDA medium without fungicides.

\section{RESULTS AND DISCUSSION}

The pathogen, G. lucidum was confirmed according to the identification key (Seo and Kirk, 2000) based on morphological and cultural characteristics. The antagonistic fungi viz., Trichoderma spp., isolated from the rhizosphere of arecanut palms were confirmed according to the identification key (Rifai, 1969) based on branching of conidiophores, shapes of phialides, emergence of phialospores and shape of phialospores. Pseudomonas fluorescens isolates were confirmed based on the identification key given by Holt et al. (1994).

\section{In vitro evaluation of antagonistic fungi against the test pathogen}

Study on antagonistic potential of fungi revealed that $T$. viride Tv-16 was the most effective in inhibiting the growth of G. lucidum in vitro. After $48 \mathrm{hrs}$ of incubation, the highest inhibition (76.26\%) was recorded in T. asperellum (Ta-7, Ta-9, Ta-10) and T. viride (Tv-16 and Tv-17). The isolates, Ta-13, Tv-21, Ta-2, Ta-3, Ta-4, Ta-5, Ta-6, Ta-8, and TV-15 showed above $60 \%$ inhibition over control. The isolates, Tv-22, Ta-14, Tv-20, T. harzianum (Th-24 and Th-23) were found to be least effective with 58.46, 58.46, $55.49,52.52$ and $40.65 \%$ inhibition. Similarly, after $96 \mathrm{hrs}$ of incubation, Tv-16 recorded the highest inhibition $(85.71 \%)$ closely followed by Ta-7 (84.71\%). However, isolates Ta-9, Ta-10, Tv-17 and Ta-12 showed above $80 \%$ inhibition (83.25, 83.25, 83.25 and $80.63 \%$, respectively). The isolates, Ta-11, Ta-13, Tv-21, Ta-3, Ta-4, Ta-5, Ta-6, Ta-8 and Tv-15 showed 79.46, 75.54, 74.10, 70.97, $70.97,70.97,70.97,70.97$ and $70.52 \%$ inhibition, respectively. Inhibitory effect of Trichoderma spp. may be due to the fact that they are known to produce large quantities of fungistatic metabolites viz., trichodermin, dermin, trichiridin, trichobrachin, etc. which are active against many soil borne plant pathogens. In vitro studies had shown that Trichoderma spp., Aspergillus spp., and Penicillum spp. were having antagonistic effect on Ganoderma. Among the bio-agents, three fungal cultures viz., T. harzianum $(63.99 \%)$, T. viride $(66.55 \%)$ and Gliocladium virens (62.12\%) had shown inhibitory effect on mycelial growth of G. lucidum after $96 \mathrm{hrs}$ of incubation (Chakrabarty and Ray, 2007). 
Table 1. Inhibitory effect of different isolates of Trichoderma spp. on radial growth of G. lucidum G9 after varying hours of incubation

\begin{tabular}{|c|c|c|c|c|c|c|}
\hline \multirow[t]{2}{*}{ Isolates } & \multicolumn{2}{|c|}{$48 \mathrm{hrs}$} & \multicolumn{2}{|c|}{$96 \mathrm{hrs}$} & \multicolumn{2}{|c|}{$144 \mathrm{hrs}$} \\
\hline & $\begin{array}{l}\text { Radial growth } \\
\qquad(\mathrm{mm})\end{array}$ & $\begin{array}{l}\% \text { inhibition } \\
\text { over control }\end{array}$ & $\begin{array}{l}\text { Radial growth } \\
\qquad(\mathrm{mm})\end{array}$ & $\begin{array}{l}\% \text { inhibition } \\
\text { over control }\end{array}$ & $\begin{array}{l}\text { Radial growth } \\
\qquad(\mathrm{mm})\end{array}$ & $\begin{array}{l}\% \text { inhibition } \\
\text { over control }\end{array}$ \\
\hline T. asperellum (Ta-1) & 12.00 & 64.39(53.36) & 18.00 & $69.85(56.70)$ & 22.23 & $75.29(60.17)$ \\
\hline T. asperellum (Ta-2) & 13.00 & $61.42(51.60)$ & 19.23 & $67.79(56.70)$ & 24.57 & $72.71(58.48)$ \\
\hline T. asperellum (Ta-3) & 11.00 & $61.42(51.60)$ & 17.35 & $70.97(57.40)$ & 20.23 & $77.52(61.67)$ \\
\hline T. asperellum (Ta-4) & 11.00 & $61.42(51.60)$ & 17.33 & $70.97(57.40)$ & 20.23 & 77.52(61.67) \\
\hline T. asperellum (Ta-5) & 11.00 & $61.42(51.60)$ & 17.33 & $70.97(57.40)$ & 20.23 & 77.52 (61.67) \\
\hline T. asperellum (Ta-6) & 11.00 & $61.42(51.60)$ & 17.33 & $70.97(57.40)$ & 20.23 & 77.52 (61.67) \\
\hline T. asperellum (Ta-7) & 8.00 & $76.26(60.84)$ & 8.53 & $84.92(67.15)$ & 10.57 & 88.26(69.93) \\
\hline T. asperellum (Ta-8) & 12.00 & 64.39(53.36) & 17.33 & $70.97(57.40)$ & 20.33 & 77.41 (61.59) \\
\hline T. asperellum (Ta-9) & 8.00 & $76.26(60.84)$ & 10.00 & $83.25(65.84)$ & 14.90 & $83.45(65.60)$ \\
\hline T. asperellum (Ta-10) & 8.00 & $76.26(60.84)$ & 10.00 & $83.25(65.84)$ & 14.33 & $84.07(66.45)$ \\
\hline T. asperellum (Ta-11) & 8.00 & $76.26(60.84)$ & 12.26 & $79.46(63.05)$ & 14.53 & $83.85(66.28)$ \\
\hline T. asperellum (Ta-12) & 8.00 & $76.26(60.84)$ & 11.56 & $80.63(63.89)$ & 14.60 & $83.78(66.28)$ \\
\hline T. asperellum (Ta-13) & 10.00 & $70.32(56.99)$ & 14.60 & $75.54(60.36)$ & 17.40 & $80.66(63.89)$ \\
\hline T. asperellum (Ta-14) & 14.00 & $58.46(49.87)$ & 19.53 & $67.29(55.12)$ & 24.57 & $72.70(58.48)$ \\
\hline T. viride (Tv-15) & 13.00 & $61.42(51.60)$ & 17.60 & $70.52(57.12)$ & 23.37 & $74.04(59.34)$ \\
\hline T. viride (Tv-16) & 8.00 & $76.26(60.84)$ & 9.00 & $85.71(67.79)$ & 10.30 & $88.56(70.20)$ \\
\hline T. viride (Tv-17) & 8.00 & $76.26(60.84)$ & 10.00 & $83.25(65.84)$ & 14.73 & $83.63(66.11)$ \\
\hline T. viride (Tv-20) & 15.00 & $55.49(48.15)$ & 20.21 & $66.15(54.42)$ & 24.63 & $72.63(58.63)$ \\
\hline T. viride (Tv-21) & 11.00 & $67.36(55.16)$ & 15.46 & $74.10(59.41)$ & 18.57 & $79.37(62.96)$ \\
\hline T. viride (Tv-22) & 14.00 & $58.46(49.87)$ & 19.60 & $67.17(55.00)$ & 24.57 & $72.71(58.48)$ \\
\hline T. harzianum (Th-23) & 20.00 & $40.65(39.61)$ & 25.33 & $57.57(55.04)$ & 29.23 & $67.52(55.23)$ \\
\hline T. harzianum (Th-24) & 16.00 & $52.52(46.44)$ & 21.43 & $64.10(49.35)$ & 24.57 & $72.71(58.48)$ \\
\hline Control & 33.70 & $0.00(0.31)$ & 59.70 & $0.00(0.31)$ & 90.00 & $0.00(0.31)$ \\
\hline CD at $5 \%$ & 1.58 & 0.010 & 6.30 & 5.06 & 0.41 & 0.32 \\
\hline
\end{tabular}

Data are the mean of four replications, Data within parentheses are angular transformed values

Among the twelve isolates of $P$. fluorescens, Pf6 was most effective $(77.55 \%)$, followed by Pf10 with $77.33 \%$ inhibition (Table 2). Biological control by using

Table 2. Inhibition of radial growth of G. lucidum by isolates of $P$. fluorescens after $144 \mathrm{hrs}$ of incubation

\begin{tabular}{lcc}
\hline Isolates & Radial growth $(\mathrm{mm})$ & \% inhibition \\
\hline Pf1 & 20.8 & $76.89(61.24)$ \\
Pf2 & 20.5 & $77.22(61.22)$ \\
Pf3 & 20.6 & $77.11(61.39)$ \\
Pf4 & 21.4 & $76.22(60.79)$ \\
Pf5 & 21.4 & $76.22(60.79)$ \\
Pf6 & 20.2 & $77.55(61.69)$ \\
Pf7 & 22.1 & $75.44(60.27)$ \\
Pf8 & 21.4 & $76.22(60.79)$ \\
Pf9 & 20.5 & $77.22(61.47)$ \\
Pf10 & 20.4 & $77.33(61.54)$ \\
Pf11 & 20.7 & $77.00(61.32)$ \\
Pf12 & 20.8 & $76.89(61.24)$ \\
control & 90.0 & $0.00(0.57)$ \\
CD at 5\% & 0.20 & 0.31 \\
\hline
\end{tabular}

Data within parentheses are the angular transformed values antagonistic micro-organisms viz., Trichoderma spp., Bacillus spp., Streptomyces sp., Mucor sp., $P$. fluorescens, etc. were found to be effective against $G$. lucidum and Fusarium oxysporum f. sp. ciceri (Wavare et al., 2017).

\section{Effect of fungicides on mycelial growth of G. Iucidum}

In vitro evaluation of fungicides provided useful information regarding its efficacy against the test pathogen (Table 3). Among the systemic fungicides, hexaconazole 5EC and tridemorph 80EC completely inhibited the growth of the test fungus at all the concentrations, whereas, carbendazim 50WP (88.44, 88.67 and $90.89 \%$ inhibition over control) and metalaxyl $8 \%+$ mancozeb 64 WP (82.00, 83.33 and $86.33 \%$ ) showed higher degree of inhibition at $0.1,0.2$ and $0.3 \%$ concentration, respectively. Among the contact fungicides, mancozeb 75WP $(81.89,83.22$ and $86.11 \%)$ gave maximum control against the pathogen, followed by copper oxychloride 50WP $(81.67,82.67$ and $86.00 \%)$ and captan 50WP (84.00, 85.89 and $85.89 \%)$ at $0.1,0.2$ and $0.3 \%$ concentrations. Fungicides - thiram, difolatan, benomyl, plantavax, vitavax and aureofungin sol + copper sulphate were found to be inhibitory to G. lucidum (Wavare et al., 2017). 
Table 3. Efficacy of fungicides against G. lucidum after $144 \mathrm{hrs}$ of incubation

\begin{tabular}{|c|c|c|c|c|c|c|}
\hline Fungicides & $\begin{array}{l}\text { Radial growth } \\
(\mathrm{mm}) \text { in } 0.1 \%\end{array}$ & \%inhibition & $\begin{array}{l}\text { Radial growth } \\
(\mathrm{mm}) \text { in } 0.2 \%\end{array}$ & $\%$ inhibition & $\begin{array}{l}\text { Radial growth } \\
(\mathrm{mm}) \text { in } 0.3 \%\end{array}$ & \%inhibition \\
\hline Carbendazim 50\%WP (bavistin) & $10.4(3.30)^{*}$ & $88.44(70.09)^{\star \star}$ & $10.2(3.27)^{*}$ & $88.67(70.30)^{\star \star}$ & $8.20(2.95)^{\star}$ & $90.89(72.40)^{\star *}$ \\
\hline Captan 50\% WP (Captaf) & $14.4(3.86)$ & $84.00(66.40)$ & $12.70(3.68)$ & $85.89(67.91)$ & $12.70(3.63)$ & $85.89(67.91)$ \\
\hline $\begin{array}{l}\text { Copper Oxychloride 50\% WP } \\
\text { (Blitox 50W) }\end{array}$ & $16.5(4.12)$ & $81.67(64.62)$ & $15.6(4.01)$ & $82.67(65.37)$ & $12.60(3.62)$ & $86.00(68.01)$ \\
\hline Hexaconazole 5\%EC(Contaf) & $00.0(0.71)$ & $100.00(89.39)$ & $00.0(0.71)$ & $100.00(89.39)$ & $00.0(0.71)$ & $100.00(89.39)$ \\
\hline Mancozeb 75\%WP(DithaneM-45) & $16.2(4.09)$ & $81.89(64.79)$ & $15.00(3.94)$ & $83.22(65.79)$ & $12.50(3.61)$ & $86.11(68.09)$ \\
\hline $\begin{array}{l}\text { Metalaxyl 8\% + Mancozeb 64\% WP } \\
\text { (Ridomil MZ-72WP) }\end{array}$ & $16.3(4.10)$ & $82.00(84.88)$ & $15.10(3.95)$ & $83.33(65.88)$ & $12.30(3.58)$ & $86.33(68.27)$ \\
\hline Tridemorph 80EC (Calixin) & $00.0(0.71)$ & $100.00(89.39)$ & $00.0(0.71)$ & $100.00(89.39)$ & $00.0(0.71)$ & $100.00(89.39)$ \\
\hline Control & $90.0(9.51)$ & $0.00(0.71)$ & $90.0(9.51)$ & $0.00(0.57)$ & $90.00(9.51)$ & $0.00(0.57)$ \\
\hline CD at $5 \%$ & 0.018 & 0.65 & 0.018 & 0.01 & 0.019 & 0.50 \\
\hline
\end{tabular}

*Data within parentheses are the square root transformed values, ${ }^{\star \star}$ Data within parentheses are the angular transformed values

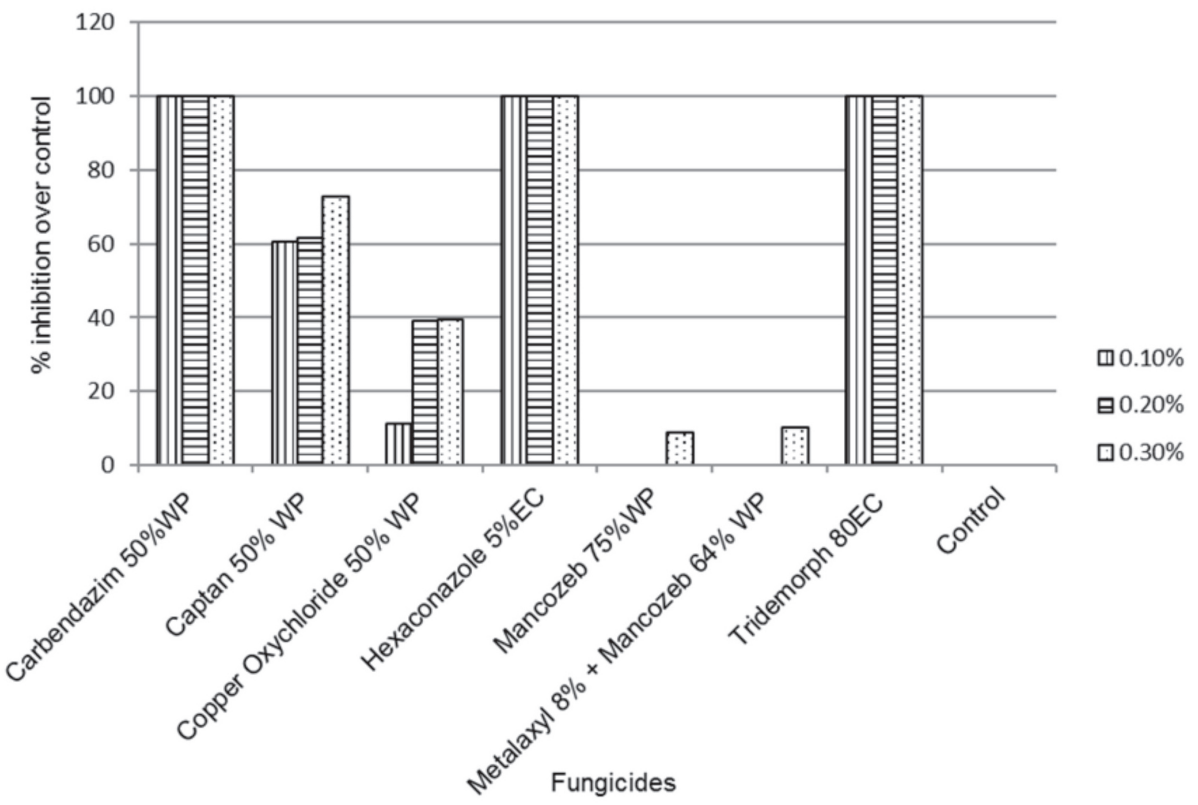

Fig. 1. Radial growth inhibition of T. viride Tv-16 by fungicides at various concentrations

\section{Compatibility study of fungicides with $T$. viride $\mathrm{Tv}-16$}

Compatibility study of fungicides with T. viride Tv-16 (Fig. 1) showed that systemic fungicides, carbendazim $50 \mathrm{WP}$, hexaconazole 5\%EC and tridemorph $80 \mathrm{EC}$ were highly sensitive to it with $100 \%$ inhibition at all the tested concentrations. Metalaxyl 8\% + mancozeb 64WP $10 \%$ inhibition) was found to be compatible at 0.1 and $0.2 \%$ concentrations, whereas, partially compatible (10.30\%) at $0.3 \%$. Non-systemic fungicides showed varying degree of sensitivity with $T$. viride. At 0.1 and $0.2 \%$ concentrations, mancozeb 75WP was found to be highly compatible, whereas, at $0.3 \%$, it was partially compatible (8.78\% inhibition on radial growth). At 0.1, 0.2 and $0.3 \%$, captan 50WP recorded 60.59, 61.59 and $72.81 \%$ inhibition on radial growth, whereas, copper oxychloride $50 \%$ WP, recorded 11.22 , 39.18 and $39.31 \%$ inhibition, respectively. The differential response of antagonistic microorganisms to various fungicides might be attributed to varying degree of inherent resistance to most of the fungicides and ability to degrade chemicals. Bagwan (2010) reported that thiram, copper oxychloride and mancozeb @ 0.2\% were compatible with T. harzianum and $T$. viride, whereas, most sensitive to captan, tebuconazole, vitavax, propiconazole and chlorothalonil.

It can be summarized that among the Trichoderma spp., T. viride Tv-16 isolate, produced maximum reduction in radial growth of $\mathrm{G}$. Iucidum followed by Ta-7 and Ta10. The isolate of $P$. fluorescens, Pf6 was most effective in reducing radial growth of the fungus. The systemic fungicides, hexaconazole 5EC and tridemorph 80EC completely inhibited the growth of G. Iucidum. Carbendazim 50\%WP, hexaconazole 5\%EC and tridemorph $80 \% \mathrm{EC}$ were highly sensitive to T. viride Tv16 with $100 \%$ inhibition. The contact fungicides, mancozeb $75 \%$ WP gave maximum control against the pathogen. Mancozeb 75\%WP was compatible, whereas copper oxychloride 50\%WP and captan 50\%WP showed low to moderate degree of compatibility with Tv-16. 


\section{REFERENCES}

Bagwan NB (2010). Evaluation of Trichoderma compatibility with fungicides, pesticides, organic cakes and botanicals for integrated management of soil borne diseases of soybean (Glycine max (L.) Murill). Int. J. Plant Prot. 3: 206-209.

Bhaskaran R, Ramadoss N and Ramachandran TK (1988). Biological control of Tanjavore wilt disease of coconut. Indian Coconut J. 19: 3-8.

Butler EJ (1909). Fomes lucidus (Leys.) Fr.- a suspected parasite. Ind. For. 35: 514-518.

Chakrabarty R and Ray AK (2007). In vitro studies on management of basal stem rot of arecanut caused by Ganoderma lucidum (Curtis ex.Fr.) Karst. J. Plant. Crops 35: 39-41.

Dhingra OD and Sinclair JB (1985). Basic Plant Pathology Methods. CRC Press, Florida, p.325.

Elad Y and Chet I (1983). Improved selective media for isolation of Trichoderma spp. or Fusarium spp. Phytoparasitica 11: 55-58.
Holt JG, Krieg NR, Sneath PHA, Staley JT and Williams ST (1994). Genus Pseudomonas. In: Bergey's manual of determinative bacteriology. (Eds. Holt JG, Krieg NR, Sneath PHA, Staley JT and Williams ST). Williams \& Wilkins. p. 93-94.

Leelavathi MS, Vani L and Pascal Reena (2014). Antimicrobial activity of Trichoderma harzianum against bacteria and fungi. Int. J. Curr. Microbiol. App. Sci. 3: 96-103.

Rifai MA (1969). A revision of the genus Trichoderma. Mycological Paper No. 116. Commonwealth Mycol. Inst. Assoc. Appl. Biologists, Kew, Surrey, England.

Seo GS and Kirk PM (2000). Ganodermataceae: Nomenclature and Classification. In: Ganoderma Diseases of Perennial Crops. (Eds. Flood J, Bridge PD and Holderness M), CAB International 2000.

Sharma SD, Mishra A, Pandey RN and Patel SJ (2001). Sensitivity of Trichoderma harzianum to fungicides. J. Mycol. Plant Pathol. 31: 251-253.

Wavare SH, Gade RM and Shitole AV (2017). Antifungal efficacy of floral extracts, biocontrol agents and fungicides against Fusarium oxysporum f. sp. ciceri 70: 191-199. 